\title{
Hydropower in the Himalayan Hazardscape: Strategic Ignorance and the Production of Unequal Risk
}

\author{
Amelie Huber \\ Institut de Ciència i Tecnologia Ambientals, Universitat Autònoma de Barcelona, 08193 Cerdanyola del Vallès, \\ Barcelona, Spain; amelie.huber@gmx.de
}

Received: 13 August 2018; Accepted: 3 January 2019; Published: 26 February 2019

\begin{abstract}
Rapidly expanding hydropower development in areas prone to geological and hydro-climatic hazards poses multiple environmental and technological risks. Yet, so far these have received scant attention in hydropower planning processes, and even in the campaigns of most citizen initiatives contesting these dams. Based on qualitative empirical research in Northeast India, this paper explores the reasons why dam safety and hazard potential are often marginal topics in hydropower governance and its contestation. Using a political ecology framework analyzing the production of unequal risks, I argue that a blind-eye to environmental risks facilitates the appropriation of economic benefits by powerful interest groups, while increasing the hazardousness of hydropower infrastructure, accelerating processes of social marginalization. More specifically, this paper brings into analytical focus the role of strategic ignorance and manufactured uncertainty in the production of risk, and explores the challenges and opportunities such knowledge politics create for public resistance against hazardous technologies. I posit that influencing the production of knowledge about risk can create a fertile terrain for contesting hazardous hydropower projects, and for promoting alternative popular conceptions of risk. These findings contribute to an emerging body of research about the implications of hydropower expansionism in the Himalayan hazardscape.
\end{abstract}

Keywords: large dams; dam safety; hazard risk; environmental governance; uncertainty; knowledge politics; marginalization; political ecology; Himalayas; India

\section{Introduction}

"[Dam safety is a matter of] calculation. When we design we take all these things into consideration ( . . . ) we assume that what we have designed will not fail. Generally, you might never have heard that a dam has failed. Maybe in Europe, but in India dam breakages are very few" (Vice-President, private hydropower company, Sikkim, 19 April 2015).

On 22 July 2018, an under-construction hydropower dam in southern Laos collapsed, killing at least 40 people, while hundreds went missing and nearly 10,000 were displaced in Laos and downstream Cambodia. Investigations in the aftermath of the disaster found faulty construction and operation and the authorities' failure to heed early warning signs to be responsible for the catastrophe [1]. Barely one month later, the South Indian state of Kerala experienced unprecedentedly severe flooding. For the first time in history, 35 out of 54 dams in the state had to be opened for safety reasons. Nearly 500 people were killed. Although various experts held the dams responsible for aggravating the floods, a report by the country's Central Water Commission quickly asserted the opposite, absolving the dams and their operators from any blame [2].

These disasters shine light on some often-neglected facts. Large dams are risk-laden artifacts. Exposed to earthquakes, floods, extreme rainfall, avalanches and landslides, and able to cause an equal number of environmental hazards, their functioning and (in)stability is ultimately a product of 
human excellence and error. As these catastrophes and numerous others in the past months, years and decades remind us, dams do sometimes fail or otherwise produce large-scale hazards. The history of the modern large dam includes a long list of dam-related disasters with a substantial human death toll [3]. This fact is often forgotten or negated, as in the above quote, partly owing to "hydro hubris" [4] - unwavering faith in the godlike power and brilliance of modern hydraulic engineering and in large dams as infallible human creations. But there are also economic and political reasons behind attempts to ignore or negate the fallibility of dams, and to erase such "accidents" from collective memory $[5,6]$. This paper analyzes the structural mechanisms and power relations behind policies and discourses, which sideline the obvious risk management challenges posed by hydropower dams.

Following the fall and resurgence of dams as "green" energy solutions and objects of financialization [3,7-9], the public debate on large dams has entered a new phase. Dominant pro-dam discourse celebrates hydropower as an uncomplicated, sustainable, and renewable source of energy indispensable to development objectives, such as green growth, climate change mitigation, and poverty alleviation $[7,10,11]$. While today the dam lobby more readily discusses mitigation strategies for contentious "externalities" like social displacement or ecological impacts, the delicate question of environmental and technological risks emanating from hydropower infrastructure rarely figures in public narratives. And yet, as the global hydropower frontier is expanding into many highly hazard-prone river basins [12,13], risk management emerges as a major challenge of environmental governance. With private and public corporations vying to tap the world's remaining unexploited rivers $[8,14]$, located often in ecologically sensitive forest and mountain areas where climate change increasingly destabilizes precarious local environmental equilibria [15-19], the question of how new hydro infrastructure interacts with environmental hazards, and how decision-makers act to mitigate and adapt to associated risks has become acutely relevant.

This study looks at risk governance in one of these new hydropower hotspots, the Eastern Himalayan region of Northeast India. Over the last two decades the rapid proliferation of new hydropower infrastructure has exacerbated ecological precarity in this seismically and geologically active mountain range [20-23]. In addition, climate change and other anthropogenic pressures are expected to accelerate the frequency and intensity of landslides, flash floods, and seasonal droughts in the coming years [15,16]. Nevertheless, climate adaptation, risk management, and disaster preparedness have received only scant attention in hydropower planning processes across the Himalayas [20,24-28]. Even for most affected communities and civil society organizations contesting hydropower development, safety risk has not been a preferred mobilizing concept - with few notable exceptions, such as the South Asia Network on Dams, Rivers and People (SANDRP), or the movements against the Tehri Dam in Uttarakhand and the Lower Subansiri Hydroelectric Project (HEP) in Arunachal Pradesh/Assam (see Section 5.2). In this article I explore the reasons why hazard potential and dam safety are often marginal topics in discussions about Himalayan hydropower governance and its contestation, and how this has helped produce and exacerbate uneven risks and vulnerabilities.

The bulk of empirical research was carried out between 2011 and 2015 in the small mountainous state of Sikkim, a late entrant to the Indian Union and a forerunner in the Himalayan race for hydropower exploitation. I conducted semi-structured and informal interviews with experts and hydropower professionals from various state departments, a German development agency, three nongovernment organizations working in the fields of environment and development, one state-owned and two private hydropower companies, as well as with local activists and rural households who deal with the ground realities. I also carried out on-site observations in seven hydropower project areas and consulted available policy documents and environmental reports, including the Sikkim State Action Plan on Climate Change [29], the Sikkim State Disaster Management Plan [30], and ten Environmental Impact Assessment (EIA) reports for hydropower projects available in the public domain [31].

Combining insights from political ecology and critical hazards geography, and from literature on the "strategic unknowns" [32], I argue that ignoring environmental and technological risks in 
the planning and implementation of hydropower projects is a central mechanism in the production of unequal risk. Turning a blind-eye to risk enables the shifting of risks and hidden costs, thereby facilitating the appropriation of economic benefits from hazardous hydropower infrastructure by political and corporate powers, and accelerating processes of social marginalization among already vulnerable social groups. Political ecologists have pointed out similar generative patterns in the production of unequal risk, as well as their underlying institutional and discursive drivers [33-37]. What has not been explored in as much depth is why and how processes of marginalization and facilitation are met with acquiescence and/or resistance by the affected public.

I try to explore the latter question by paying attention to how knowledge politics mediate the production and contestation of risk $[32,38,39]$. I show how certain experts and hydropower professionals instrumentalize and manufacture scientific uncertainty and controversy to depoliticize and conceal the subject of risk in dam conflicts [40]. By contrasting the Sikkim experience with a second case study from the Eastern Himalayas-the protracted conflict over the 2000 MW Lower Subansiri Hydroelectric Project on the Assam-Arunachal Pradesh border-I discuss how knowledge politics can serve to curb resistance, while at the same time providing a fertile terrain for contestation. Thus, the conflict over the Lower Subansiri project-one of India's largest hydropower projects under construction to date-turned into a highly politicized public controversy precisely because civil society groups were able to draw on both vernacular knowledge and scientific expertise to challenge techno-scientific hubris and knowledge politics with powerful counter-claims.

The paper is structured as follows. Section 2 theoretically situates the paper. Section 3 discusses the inherent and aggravated risks associated with the Himalayan dam building spree. Section 4 looks at the hydropower governance process, analyzing institutional mechanisms and policy lacunae, which facilitate "risky" hydropower projects and foster relational processes of facilitation and marginalization. Section 5 first illustrates how these processes are reinforced through a politics of ignorance and neglect, which is legitimized through the mobilization and manufacture of uncertainty. It then discusses the challenges and opportunities for publicly resisting such discursive strategies, making a case for lay-expert knowledge co-production. Section 6 concludes with theoretical and policy implications.

\section{Theoretical Framework}

Political ecologists and critical hazard geographers have long argued against hazard-centric and techno-managerial approaches to the study and management of environmental risks, which locate the blame for calamity in nature [41-43], pointing instead to the social, structural, political, and institutional dynamics, which produce risk, disaster, and differential vulnerabilities $[34,35,44]$. Often those further down the social ladder have to pay for natural disasters-a result of power relations, structural inequalities and exploitative processes, which allow those who create or decide for risk, intentionally or through ignorance, to shift it onto others who lack the power to influence these decisions [45]. A common frame in hazards geography thus defines risk as the combination of the probability of a biophysical or technological hazard event (e.g., an earthquake or a dam failure), hazard exposure and social vulnerability ("the ability to anticipate, respond to, and recover" from the inflicted damage [33,44,46] (p. 589).

Recent studies have moreover emphasized the importance of analyzing the generative processes, systemic drivers and institutional decisions, which produce unequal risk and differential vulnerabilities, particularly those enhanced by neoliberalism and capitalism [47-49]. Baldwin and Stanley [46], for example, conceptualize environmental risks and hazards not merely as by-products of capitalism, but as integral to the circulation, viabilities, and crises of capital. Huber et al. [6] suggest that in order to give greater visibility to the role of capital in driving "risky" development decisions, dam failures and other so-called "socially constructed disasters" should better be characterized as "capital-driven destructions".

Similarly, research on environmental justice and environmental racism has shown how racially uneven geographies of risk and vulnerability are the product of colonial ecological violence during 
the early days of modern capitalism and its postcolonial iterations today $[25,50]$. In the context of the Eastern Himalayas, Gergan [25] argues that hazardous hydropower infrastructure is built on historical terrains marked by the relationship of dependency, exploitation and negation between the Indian state and its northeastern frontier, and by generations of regional marginalization, uneven development, and racialized, exclusionary state-building practices.

A useful analytical frame to understand how capital interests and elite social groups benefit from the creation of unequal risk is Collins' [33] relational concept of marginalization and facilitation. It highlights multi-dimensional, mutually constitutive and materially inseparable social constructions of nature, which turn environmental risks simultaneously into amenities for some, and externally imposed threats for others. Specifically, facilitation denotes "how powerful groups are provided privileged access to institutional resources" to exploit the environmental rewards associated with hazardous places, with deleterious socioenvironmental outcomes (p. 589). This definition emphasizes the integral role of state and market institutions in unevenly allocating protective resources, such as insurance, land-use and disaster relief subsidies [33,36,37]. In Collins' [33] example, wealthy US residents appropriated the environmental rewards of living in flood-prone neighborhoods (scenic views and being amidst nature) by securing privileged access to flood recovery resources and institutional support. Risks were thus externalized and shifted onto poor migrant workers (marginalization) who occupied flood-prone neighborhoods for want of options, while lacking access to a similar safety net.

But processes of marginalization and facilitation and the uneven geographies of risk and vulnerability they create are also a product of analytical lenses and discursive formations-often based on expert knowledge systems and technocratic managerial discourses-through which they are viewed, represented, and contested [33,34]. Mustafa [35], for example, in his work on the technocratic production of an urban flood "hazardscape" in Pakistan argued that the authorities' material interventions in the watershed were heavily influenced by a narrow technocratic view of hazard problems and solutions, which was largely incongruent with the lived hazardscape reality of the flood victims. Such narrow technical framings of contested environmental problems may also be used strategically to depoliticize and cover up value conflicts, to justify decisions already made [51], or to facilitate the shifting of the harmful effects of accumulation through hazardous technologies [52].

Similarly, one of the main objectives for scholars of ignorance studies has been to show how ignorance, knowledge gaps, or "undone science" are used strategically to preclude, obfuscate, deflect and insulate against unsettling information, magnifying what remains unintelligible [32,38,39,53,54]. As McGoey [32] argues, "the cultivation of strategic unknowns remains ( ... ) perhaps the greatest resource for those in a position of power" (p. 1), a "productive asset helping individuals and institutions to command resources, deny liability in the aftermath of crises, and to assert expertise in the face of unpredictable outcomes" [28,55] (p. 553). Industries, for example, increasingly take advantage of uncertain evidence - or question the validity of existing evidence - to shroud claims of causal linkages and to protect financial interests, as was the case with the tobacco industry, climate skeptics or the 2008 financial crash $[40,55,56]$.

In the Himalayan hydropower sector, too, the strategic mobilization of the "unknowns" about environmental and technological risks is a pervasive practice employed both by state and corporate actors [32]. Lord [28,57] and Butler and Rest [24] explore how the "speculative logics" of private financial interests and the state's ambition to meet demands of domestic electricity and revenue propel state and corporate actors within Nepal's hydropower community into "environmental denial" [24] (p. 15), "perpetuat(ing) a "strategic ignorance" [32] of palpable environmental and infrastructural risks" [57]. In a "conjuring trick (and) spectacle" aimed at gathering investments and maintaining the promise of a "hydropower nation", hydropower proponents gloss over inherent environmental and technological uncertainties (e.g., that of seismic risk), while championing "an understanding of risk as objectively calculable" $[9,24]$ (pp. 21-22).

This paper delves deeper into the material and discursive process enrolled to invisibilize the hydro-climatic, geological, and technological risks of large-scale hydropower development in Sikkim. 
While many of these risks are known in principle, the incalculability of their occurrence, timing and scale allows experts and political decision-makers to overlook, ignore and deliberately conceal them, much like the knowledge politics surrounding climate change allow some to argue climate change is a hoax.

A further concern of this paper is the role of risk conflict and public resistance in processes creating unequal risk, and in attempts to challenge manufactured uncertainty. The "hazardscape" concept invoked by Mustafa [35] and Collins [33] frames geographies of uneven risk as products of contestation between competing social groups. However, the discussion on what determines public resistance or compliance with the policies and discourses responsible for risk creation has remained relatively thin. Leaning on Gramsci [58], Collins [33] (p. 600) argues that some hegemonic discourses are invoked "even by people who appear to be poorly served by them," because marginalization—being predicated on unequal power relations-is often legitimized ideologically.

Alternatively, people may be aware of and challenge the technocratic gaze and the power dynamics that put them at risk; yet, they fail to transform existing configurations of power and injustice due to the differentially powerful epistemic authority of popular epistemologies vis-à-vis policy and science-based knowledge claims. In a "globalizing world, characterized by the hegemony of technocratic and social modernity", it is this "power of modern institutions to limit debate and discussion" that prevents a more democratic approach to risk management [35] (pp. 567, 582).

The literature on risk conflicts paints a more hopeful picture for the contestation of dominant risk discourses from below. Contrary to popular claims about science being indispensable for understanding many of today's "invisible", diffuse, and difficult to perceive risks [59-61], scholars argue that increasing awareness among the lay public and reduced appreciation for science as a privileged, authoritative source of knowledge create new opportunities to influence definitions of risks. As Cooper and Bulmer [62] (p. 264) argue, hegemonic expert discourses about risk can be hijacked and altered by counter-hegemonic forces, promoting "contradictory popular conceptions of risk". While the greater contestability of knowledge also implies that politically powerful interest groups can reject valid scientific evidence as "fake news" [40,56], it has also given rise to new risk conflicts [59,60,63-65], allowing grounded, material, and embodied experiences of environmental precarity to converse with and challenge scientific representations of risk [25].

This paper seeks to contribute to these debates about acquiescence and resistance to the production of unequal risk, by making a case for knowledge controversy as a major site of political struggle and contestation. It contrasts two cases of risk conflict over hazardous hydropower infrastructure: in the first, scientific uncertainty was effectively mobilized and reinforced by government experts, decision-makers and power developers to maintain the status quo of undefined liabilities; in the second, the ambiguity and malleability of science was exposed and exploited to stage alternative risk claims and to re-politicize the risk question.

\section{Hydropower Risks in an Intensifying Hazardscape}

The Himalayas are naturally hazard-prone. As one of the world's most geologically and seismically active mountain ranges transected by a multitude of steep, fast-flowing, silt-laden rivers, earthquakes, landslides, and floods are recurrent phenomena. Yet, anthropogenic activities including urbanization, deforestation and infrastructure development have led to an intensification of hazard potential in recent decades [66,67]. Further, severe climate change effects on the weather-climate and hydrological regimes of the Himalayan region have been observed and predicted for the coming decades [15,68-70], increasing in particular the risk of landslides and large-scale hydrogeological hazards, such as "landslide dam outburst floods", "glacial lake outburst floods" (GLOFs) and other erosive flash floods $[16,27,71]$.

Recent disasters hint at how vulnerable Himalayan hydropower projects are. In 2013, an extreme flash flood in the Indian state Uttarakhand caused extensive damage to the state's hydropower infrastructure as an excess of water, boulders, debris, and silt choked the floodgates of hydropower 
stations, leading to overtopping [72]. A similar problem was caused by a landslide dam outburst flood in Nepal's Sunkoshi river basin in 2014 [73]. During the devastating 2015 Nepal earthquakes over 30 hydro projects were damaged, mostly by earthquake-triggered landslides, causing the loss of $34 \%$ of Nepal's installed hydropower capacity and USD 200 million estimated losses for its hydropower industry [28,74]. Schwanghardt et al. [74] estimate that $25 \%$ of existing and planned Himalayan hydropower projects "have high probabilities of moderate to severe damage during future earthquakes".

But hydropower infrastructure is not only at risk. It also contributes to the intensification of hazard potential, often as a consequence of political and economic decisions about its siting, construction and operation. Schwanghardt et al. [75] (p. 1) observe a systematic push of hydropower activities into the headwaters of Himalayan river basins, closer to glacial lakes and on potential GLOF tracks, estimating that a third of the sampled sites "could experience GLOF discharges well above local design floods." Likewise, investigations identified hydropower infrastructure as one of the main contributors to the Uttarakhand flood damage [72]. Damage was greater near existing and under-construction hydro-projects-a result of how these projects manage destructive water and sediment flows. Construction debris was inadequately disposed of and washed into reservoirs, obstructing dam/barrage gates and leading the river to overflow and laterally outflank the dams. Excessive siltation had reduced the carrying capacity of rivers and increased their erosive capacity.

Dam-induced flash floods are a recurrent problem, caused by sudden releases of water from hydropower stations. Designed primarily for power generation, most run-of-the-river projects today lack adequate flood cushions, as Das [27] explains. Especially at times when reservoirs are full (e.g., at the end of the monsoon season), flood absorption is not guaranteed-a fact often brushed over by hydropower proponents. When excessive inflows from floods or heavy rainfall exceed storage capacity, it is standard practice to release water to ensure dam safety. But such patterns of water release can be highly disruptive, accentuating flood impacts downstream (ibid.), as has been most cruelly demonstrated by the massive flood disaster in Kerala this year [2].

Finally, what is easily overlooked, especially when thinking in terms of large-scale dam disasters, is the "slow violence" of everyday ecological precarity accompanying the construction of hydropower infrastructure in fragile geological settings $[25,76]$. Phenomena reported from hydropower-affected areas across the Himalayas, such as the sudden appearance of cracks in houses, the activation of landslide zones, or water resources running dry may represent more tangible and cumulatively impactful hazards to the lives and livelihoods of rural Himalayan communities [26,57,77-79]. Excavation works for hydropower infrastructure tend to destabilize fragile mountain slopes, with impacts often felt for months or years post-construction, exacerbated by natural hazard activity. For instance, following a 6.9 magnitude earthquake in Sikkim in 2011, a particularly large concentration of earthquake-induced landslides and damaged buildings was found in vicinity of the $1200 \mathrm{MW}$ Teesta III HEP under construction at the time [22,80]. As a prominent Sikkimese activist commented: "It is any one's guess that the severely disturbed area just needed another jolt to cause devastation as that happened on the 18th of Sept 2011." [81].

Despite these obvious environmental risks, prevalent hydropower governance approaches in Himalayan states have brushed risk and safety considerations under the carpet, often due to economic considerations [24,26,28,82]. Sikkim, given its reputation as one of India's most environmentally conscious states would appear more likely to approach hydropower governance in a more holistic manner [11]. However, as I discuss in the following sections, analysis of governance approaches with respect to hydropower risks exposes serious shortcomings behind Sikkim's progressive "green" politics façade. The government's "quick-business" approach to hydropower development and efforts at providing favorable investment conditions have not only invited "risky" hydropower projects but have also accentuated vulnerabilities in marginal rural areas. 


\section{Hydropower Governance and the Production of Unequal Risk}

\subsection{Facilitating Risk through Privatization Policies}

Large-scale privatization gave the impetus for the Himalayan hydropower boom [83]. With the bad fame large dams had acquired globally by 2000-following persistent civil society activism and the World Commission on Dams' staggering report-international finance for large dams had become scarce $[3,84,85]$. Privatization was widely embraced to revive an ailing hydropower industry [85]. In India, liberalization was gradually initiated with the Mega Power Policy 1995 and a number of other policies followed suit. The launch of the 50,000 MW Hydro Initiative in 2003 promulgated a discourse of sustainable hydropower as imperative for satisfying India's escalating energy demand and identified the country's exploitable hydropower reserves, predominantly located in difficult to access borderland mountain regions [83]. To attract private investments, the policy framework pledged financial support; fostered deregulation of the renewable energy market, minimizing state intervention; relaxed clearance procedures; reduced the minimum threshold capacity for so-called 'mega' power projects to increase the number of projects eligible for the attendant benefits"; and gave state governments the power to allot projects $[86,87]$. In Sikkim, investments were further incentivized by extending a 10-year tax and import duty exemption and by facilitating land acquisition and accelerated clearances through the government [86].

The Eastern Himalayas were labelled "India's future powerhouse" [27]. Here, privatization kick-started a race by the states of Sikkim and Arunachal Pradesh to contract out public rivers to private power producers $[27,86]$. These being predominantly rural, non-industrial states, hydropower was presented as a major source of revenue, greater financial and political autonomy, urgently needed infrastructure, employment, and regional development [11]. By 2007, Sikkim had signed 24 Memoranda of Understanding (MoUs) with selected private and public-sector undertakings for developing $5000 \mathrm{MW}$ within five years [86]. Private undertakings were allocated on "Build-Own-Operate-Transfer" basis for 35 years (after which projects are handed back to the state in good operating condition), with the state entitled to $12-15 \%$ of the generated power/revenue and $26 \%$ equity for projects above $100 \mathrm{MW}$ developed in joint venture [88]. Arunachal Pradesh signed 130 MoUs by 2010 for $40,140.15 \mathrm{MW}$ installed capacity and 26\% equity committed to each [27].

With neither a formal hydropower policy nor written rules for public-private financial transactions [87,89], this so-called "MoU virus" thrived on speculative investments and political brokering [27] (p. 3). Agreements with private sector companies allowed for "greater flexibility in negotiating financially lucrative deals" [83] (p. 15), and involved large upfront premiums and individual commissions [27]. Critics lamented that projects were allocated arbitrarily and at "throwaway charges", lacking transparency and competitiveness [90] (p. 738).

A consequence of this open-arms approach has been what Hill [90] (ibid.) calls "frontier capitalism": the entrance of private investors with minimal accountability and experience in hydro, including from the courier and logistics, real estate, steel fabrication, and tourism sectors [91]. As a result, many projects under construction were eventually stalled or abandoned due to financial insolvency (in Sikkim only five private-held projects have been commissioned as of 2018) [20]. The hydropower sell-out has also invited public suspicion about a massive scam involving "private deals, covert decision-making and corruption", as well as the sale of the procured memoranda, clearance papers, and licenses for profit [92] (p. 56). As Rahman [91] (p.19) notes about the similar situation in Arunachal Pradesh:

"There have been allegations that many dubious private companies are raising huge capital in the stock market, increasing their market profile and bagging infrastructure projects in other under-developed countries on the back of such hydroelectric project allocations ( ... ) The local perception is that many of these small and medium dam projects are 'paper dams' or 'MoU dams' and will not see any construction on the ground, as there have been no signs of urgency in ground assessment and feasibility studies." 
By incentivizing and facilitating this fast-tracked and intransparent hydro-business model, privatization policies have prepared the ground for inequitable and "risky" dam projects. For example, India's Hydropower Policy 2008 contains a number of generous concessions, which insulate private companies from the majority of risks inherent to the sector (e.g., hydrological risk), shifting these onto the public, while maximizing the margin for profits and ultimately raising the costs of power [27]. Thus, the imposed tariff regime gives power producers no economic incentive to optimize project designs according to comprehensive hydrological data. Producers are paid for full "design energy" generation, even when water is scarce and power generation is low, while buyers pay more for less. The result, Vagholikar [93] argues, are "over-designed" dams based on unrealistic data.

Moreover, joint ventures "reduce the distance between project regulators and implementers" [89] (p. 118), affecting enforcement and compliance with environmental clearance and environmental management requirements [27]. Vagholikar and Das (ibid. p. 3) note that projects allocated through preliminary payments tend to be seen by both parties as a fait accompli. Even the Ministry of Environment and Forests (MoEF) is known to proactively grant clearances to $95 \%$ of the appraised projects, including for EIA reports of extremely poor quality, or which have been "sanitized by developers ( ... to weed out problematic portions" (p. 5), ignoring concerns raised by civil society. In Sikkim, lack of regulatory oversight and willful ignorance have permitted environmental decision-making frameworks to be easily sidestepped, resulting in "regulatory collapse" [22] (p. 20). By 2011, at least 17 HEPs had received environmental clearance despite warnings, improper assessments, and without meeting negotiated conditions or addressing regulatory violations (ibid.).

The following sub-section looks more closely at the ground effects of existing policy frameworks and state-level governance decisions, illustrating how these have obscured liabilities, thereby producing increased ecological precarity and social vulnerability in hydropower areas.

\subsection{Producing and Shifting Risks and Costs}

The project giving the best insights on long-term hydropower impacts is the 510 MW Teesta V HEP in Central Sikkim, one of the first large dam projects in Sikkim, commissioned in 2008 by the public-sector National Hydroelectric Power Corporation (NHPC). During household interviews in the area directly affected by the project's infrastructure, environmental degradation was reported by various communities in the project area-spanning a $20 \mathrm{~km}$-long stretch of the Teesta river-but was found to be most severe above the reservoir and dam site. The villages Jang, Aapdara, and Phidang have been struggling with perpetual sinking of the mountain slope on which they are located, likely a consequence of the cyclical release of impounded water [94]. Visible damage included cracks in residential buildings and agricultural land, as well as enhanced landslide activity.

This has created a situation of unanticipated displacement during and sometimes long after project construction. In Aapdara and Jang several residential buildings have collapsed, and families been relocated from the area. The safety risk has become so pronounced that plans are underway to move the entire village. In Phidang the reservoir backwater has come dangerously close to the settlement, and lower lying areas of the village are at risk of toe erosion and flash floods, including sudden water releases by planned and existing dams upstream. Here, too, respondents were considering abandoning their properties. In Dipudara, located above the vertical tunnel carrying water to the powerhouse, water was repeatedly found flowing from 'cracks' in the mountain within one year of commissioning, raising fears that the tunnel system may be faulty and risk collapsing. The villagers have since been demanding compensation and resettlement.

Negligent construction practices can partly be blamed for increased ecological precarity. For example, despite knowledge about the fragile geology NHPC didn't implement effective precautionary measures, such as reservoir rim treatment [94]. In Dipudara, slope stabilization and protective concreting works to mitigate tunnel leaks were reportedly ineffective, rendering the land increasingly unsuitable for agriculture and construction. Excessive amounts of explosives used to 
accelerate tunnel construction was another problem cited (Interview, Mines, Minerals \& Geology Department, Government of Sikkim, 26 April 2011).

Such corporate negligence, however, has also been institutionally facilitated, notably by failing to hold developers accountable. First, India's rehabilitation and resettlement policy considers only land users whose lands are acquired prior to project construction as project-affected and entitled to compensation and rehabilitation. These provisions may work for dam projects with 'traditional' storage designs. Modern large-scale run-of-the-river hydropower projects-the new standard dam design in the Himalayas-have smaller submergence zones but require an extensive underground tunnel system carrying river water to a powerhouse located several kilometers downstream [27]. These tunnels affect places far away from reservoir and power house, often in ways that are not immediately obvious (see Section 5.1). In Sikkim, entire hillslopes are pierced by tunnels or nibbled at by water-level fluctuations in the reservoir, but the often-irreversible damage and displacement caused, sometimes years after project completion, is systematically ignored in EIAs because policy does not mandate land acquisition in such areas. (For an alternative rehabilitation and resettlement model see Lord's discussion of the Upper Tamakoshi HEP in Nepal [28].

Second, for impacts not accounted for in the EIA it is difficult to claim compensation and "project-affected person" status later. Without clearly formulated guidelines defining liabilities, and authorities unwilling to hold power developers accountable, the latter can easily shirk responsibility. The burden of proof is shifted onto the victims, but laypeople have been unable to prove that the observed impacts are caused by the project. While victims receive financial support through a 'natural calamity fund' from the district administration, access to these resources often hinges on social status and connections to influential decision-makers. As one interviewee tellingly suggests: "Compensation is not dealt out to all households, only to the rich. After all, cracks cannot be seen in simple huts" (24 February 2011).

The authorities' failure to efficiently handle rehabilitation claims further propounds the vulnerability of those affected. In Aapdara and Jang inhabitants still lived in visibly damaged buildings since their compensation payments had not yet been settled. One displaced landowner received Rs $10,000(€ 160)$ on the spot for immediate relief but was told that a full damage assessment, to be conducted by a different department was required to compensate his entire loss. After ten months and 19 visits to different offices he still had no news. Such bureaucratic limbo hits economically weak households unable to self-fund safety measures particularly hard. Lengthy administrative procedures, trips to offices and possible legal fees cut further into tight household budgets, and struggling for rehabilitation also requires a certain level of education and political clout.

This is not to say developers are totally uncooperative. In some cases, NHPC agreed to compensate the damages incurred-either through voluntarily ex gratia payments to the victims, or by repairing or constructing public infrastructure. Such voluntary rehabilitation assistance appeases public relations and avoids negative publicity, but it also undermines a more drastic reconfiguration of the rules of the game. As one Sikkimese journalist relates:

“NHPC is generous in dealing out compensation money and undertaking protection works but refuses to admit on paper that the project works are responsible for the damage. If they would, the calculations for future projects would have to be expanded. However, in this way the same underrating of impacts is likely repeated with the next project or EIA. NHPC is also very quick in doing the repairs because in this way they control the works and the contractors too" (24 February 2011).

A more impactful way to address the vulnerabilities created by hydropower development would be policy amendments, which establish on paper the range of (hydro-)geological disturbances hydropower infrastructure can cause; and which define corporate liabilities for social and environmental rehabilitation at any project stage, preventively or through aftercare. But institutional consequences are not in the economic interest of the developers, nor of the local elites, who gain 
kick-backs and contracts through the hydropower business. Thus, avoiding that certain environmental risks and impacts become officially recognized and their assessment and mitigation institutionalized is key to cost-cutting and a continuation of business-as-usual. The following section explores this process of "strategic denial" by government experts, politicians and power developers within Sikkim's hydropower community further [24,57]. It illustrates how scientific uncertainty about hydropower risks and impacts is fostered through individual and institutional complacency, and by manipulating knowledge production.

\section{Risk, Knowledge, and Resistance}

\subsection{The Politics of Knowledge around Hydropower Risks}

Dam sanctioning guidelines in India do contain provisions to assess risks and ensure dam safety. Detailed project reports (DPRs) drafted during the dam planning stage must contain seismic studies and dam design and safety parameters in accordance with the Bureau of Indian Standard's civil and hydraulic engineering codes [87]. Further, states must prepare dam operation manuals for individual dam projects, which contain an emergency action plan [2]. However, there are other risks - many—which are not or insufficiently accounted for through the national policy framework [87]. For example, a major risk management challenge, given the fast proliferation of hydropower projects in a context of heightened ecological precarity and climatic uncertainty, is reconciling hydropower development with climate action and disaster management. Yet, since not mandated, none of the publicly available EIA reports and Environmental Management Plans for hydropower projects in Sikkim contain climate change considerations. Even the newly named national Ministry of Environment, Forests, and Climate Change does not have any written positions on climate change adaptation for the hydropower sector [87].

Likewise, Sikkim's in many ways progressive environmental policy framework largely ignores the critical hydro-climate-disaster intersection, failing to keep in mind inherent ecological precarity [20,25]. Sikkim's State Action Plan on Climate Change elaborates at length on water resource vulnerability and water security but steers clear of hydropower and associated environmental risks [29]. Investigations with the State Disaster Management Authority (SDMA) found that so far neither are there risk assessments for dam-induced disasters, nor disaster management provisions to deal with hydropower-related risks. Even the department head admitted that dam safety standards were exclusively monitored by the project developers themselves, while the state was ill-prepared to deal with hydropower-related hazards:

"We are not monitoring [the power companies] ( . . ) As a disaster management department, we should be going to the dam, but now they themselves have scientists and technical persons ( ... We should also have a connection, but now we are busy with some other things. Later we'll be doing that also" (7 May 2015).

Interviews with experts and hydro professionals reflected a striking disregard and ambiguity about dam safety, even among senior government officials. Several respondents tried to downplay or deny the hazard potential of hydropower, or to retreat from responsibility. An interviewee in the Power Department suggested I better go ask these questions to the Forest Department, since they are the ones dealing with environmental impacts and climate change (11 May 2015). There seemed to be a general lack of mandate by the authorities to look at the effects of climate change on hydropower infrastructure. An interviewee at the German development agency supporting the drafting of a state climate change policy said he was aware of climate change impacts on hydropower, and hydropower impacts on the environment, but explained that his agency only works "on whatever the government will request" (2 December 2013).

To justify this lack of engagement with hydropower risks several interviewees invoked scientific uncertainty and knowledge controversy. One NHPC official explained that in the absence of scientific climate data, climate change was a factor too uncertain for consideration in his project's EIA report: 
"This is something that has to be established first (scientifically) ( . . . ) Somebody else has to do it" (8 November 2013). Some respondents disputed that climate change poses a problem at all. The head of the disaster management department, for example, opined that for him as a geologist, climate change was "sort of a political issue", rather than a "real" scientific phenomenon to be taken seriously (7 May 2015).

Uncertainty regarding the intensity, timing and spatial effects of climate change is undoubtedly more pronounced in the Himalayas, not least due to the lack of basic, reliable, long-term climate data for the region [27]. However, responses by project developers indicated that neglecting rather than mitigating potential environmental risks and their social ramifications was at least partly an economic strategy for safeguarding the financial viability of hydropower investments. Since the companies usually try to recover their investments as quickly as possible, and since from an economic perspective structural safety loses its importance as time advances (especially for licenses lasting merely 35 years), investing in costly precautionary measures not prescribed in project plans cuts into narrowly calculated returns. Responses also reflected that for the developers, environmental risks and their mitigation were calculable problems. Asked how his company deals with natural hazards, the director of a private power company commented: "You have to put up with it. If it harms the project, we have to bear it. We take insurance. ( . . ) That is a must. That is a condition put by the lenders. Because after all they get the money back" (15 May 2015).

The strategic use of knowledge gaps also became evident from the rather selective framing of uncertainty. For example, despite the inherent and inevitable uncertainties associated with complex technological systems like dams [38], dam safety concerns were either brushed aside, or exalted with "hope" or "faith" in state-of-the-art technology, and the blunt denial of historical dam failures. The following statements were made by engineers and scientists in the Power and Disaster Management departments, the Central Water Commission and by a private hydropower company director:

"We expect earthquakes ( ... ) and damage is inevitable. Some damage happens, it is designed that way. But to totally fail and all, that's not going to happen. Hopefully" (11 May 2015).

"There are so many components, which should be earthquake resilient features. If that is done, then there is no issue that it shouldn't hold the intensity of an earthquake with a magnitude of around 8. I think they are made to hold this 8" (7 May 2015).

"The geology is very fragile here and the conditions of the rock are not very good. But everything has engineering solutions and that's what we do provide. From the geological and engineering point of view, there are no problems. For every geological problem there is an engineering solution available." (8 May 2015).

"Dam break analysis has been done by the Institute of Roorkee based on which the dam has been designed. ( . . ) In India, it has never happened. No dam has broken till now. Once the dam break analysis is done, it is ensured that the reinforcement and construction methodology used are fool-proof" (5 May 2015)

But uncertainty was not only discursively framed. Its active reinforcement, both by dismissing non-scientific sources of information and by obstructing the generation of scientific evidence is illustrated by the controversy about the hydrogeological impacts of hydropower tunnels. Local people in various project-affected villages in Sikkim have noted declining agricultural productivity, along with the sinking and degradation (cracking) of land, the depletion of soil moisture, and the drying and disappearance of springs-predominant source of domestic and agricultural water. Especially farmers who observed such changes daily were unanimous that these problems were caused by hydropower tunnels, which they argued "swallow" and divert soil moisture and spring water, evidenced by rivulets emerging from the tunnel access points. Likewise, they associated land degradation with 
tunnel blasting, (which "made the land shake just like during an earthquake,") and recalled starting to witness these changes roughly when project construction began.

While the locals believed to have an answer, science did not. A spring expert explained the difficulties in scientifically pinpointing the causes of hydrogeological change, with current scientific understanding of Himalayan hydrogeological systems being too coarse and qualitative, due to their complexity and location-specificity, and available research methods being too resource-intensive (2 May 2015). He nevertheless suggested that a multi-site study analyzing the state of the environment before and after project construction could explore scientifically valid linkages between tunneling and spring decline. However, when I enquired about such studies with the Department of Mines and Geology, the state agency responsible for (hydro)geological assessments, the geologists there were disheartened. While their team had carried out damage assessments in three project-affected areas, confirming many of the locals' assumptions, their findings couldn't be considered "legitimate" evidence, since the assessments were exclusively carried out after the changes had occurred. A systematic baseline inventory of landslide zones and spring discharge prior to tunneling had never been commissioned:

"We tried to have baseline data earlier, but we could not do it. I tried to convince the government, this is the main requirement. Because a lot of comparisons will come up at a later stage. ( . . ) I insisted to carry out such studies, either they should be financed by the power projects, or they [themselves] should carry out those studies."

"So, you couldn't carry out these studies even though you wanted to?"

"These power developers are such influential people, they can influence the government also."

"But isn't there any incentive for the government to carry out these kinds of studies?"

“They have not initiated. [Why] I don't know exactly. Because the government is interested in harnessing all the power" (26 April 2011)

Even four years later, despite further ex-post reports confirming extensive environmental degradation in project-affected areas, the government had still not made any efforts to establish the extent and causes of these damages. Only one project developer had apparently agreed to collect baseline data before starting tunnel excavation (6 May 2015).

In the absence of sufficient scientific-experimental data and for system dynamics difficult to explain with scientific methods, vernacular forms of knowledge, based on historic memory, long-term observations and an intimate understanding of the local environment have become important sources of information to better understand patterns of climate and environmental change in the Himalayas $[95,96]$. Even Sikkim's acclaimed rural development program "Dhara Vikas", which revives springs to ensure water security in drought-prone villages uses local perceptions as a main data input [97].

In most expert interviews about hydropower impacts, on the other hand, vernacular knowledge was categorically dismissed as insufficient or invalid, rumors and "misconceptions" resulting from ignorance, illiteracy, or political motivations, and pitted against science as the only valid source of information. A common argument was that Sikkim's geology is "naturally" fragile and multiple other factors may influence hydrogeological processes. An official in the Rural Management and Development Department suggested that locals blame the tunnels because they produce sudden changes and are highly visible, but how sure can the locals be? "Actually, we need some scientific evidence" (8 May 2015). An engineer with the Central Water Commission got rather worked up by my question and the account of the villagers' perceptions:

"After making the tunnels, it has not been observed anywhere that the resources have dried up. ( . . . ) How can it be? It's basically a foolish question. Those who are asking those questions, they don't have a basic knowledge of engineering. ( ... ) There is no valid reason, 
no engineering reason that water will be depleted. ( ... ) People are either making false statements or it is just against hydropower. Unnecessary rumors are being created ( ... ) Because in our village areas ( . . ) the literacy rate [is] less than 10 per cent, people have not studied even 4 th and 5th standard. ( ... ) If you tell them that the sun rises in the west, they will be convinced by that" (8 May 2015).

\subsection{Contesting Dominant Risk Discourses}

Quantitative, techno-scientific representations of risk often have a depoliticizing effect on environmental governance, compromising public political deliberation and democratic decision-making. As Anderson [98] (p. 41) argues, by employing an "end-eschewing mode of argument" and presenting fundamentally political and ideological choices as technically complex, scientific issues, such discourses disqualify the scientifically illiterate from debates about risk, making risk "the exclusive province of the expert". Expert representations of environmental and technological risk may also serve hidden agendas of profit and power:

"When a certain (warped) technical rationale is presented as the standard of rationality it is really an unacknowledged form of political domination, one that facilitates the selection of a particular kind of society as it obscures this end from public political discourse. Naturally, we find this mode of argumentation advanced by those who stand to lose the most from free democratic discussion - those who represent corporate and state power" (p. 43)

Equivalent arguments by political ecologists speak about the capture of environmental discourse and risk controversies in a "post-political consensus", concealing that what really is at stake in environmental politics is a democratic-ideological struggle between different socio-environmental futures $[99,100]$.

Similarly, in India, the high degree of epistemic authority awarded to science vests experts with the exclusive power to determine which risks are real or unreal, allowing no room for lay knowledge claims to contribute even to problems associated with great scientific uncertainty. This erasure of risk by invisibilizing and excluding certain risks from the terms of the debate presents a major obstacle to public resistance against hazardous hydropower projects. The entire burden of proof is shifted onto affected households-often the most vulnerable social groups who have little to no means to consult expert opinions, mount campaigns or enter litigation and exert political pressure.

Yet, while uncertainty and knowledge politics lend themselves to manipulation, they also represent a fertile terrain for contestation. Research suggests that in the age of manufactured, diffuse or invisible risks [59-61], the reduced appreciation of science as an exclusive, authoritative source of knowledge gives alternative knowledge claims more influence over definitions and debates about risks-one reason for the growing number of risk conflicts [59,60,63-65]. As the struggle against the Lower Subansiri mega-hydro project on the Assam-Arunachal Pradesh border illustrates, influencing the production of knowledge about risk can be a most effective strategy for challenging expert representations of risk and the top-down imposition of hazardous technologies.

NHPC's 2000 MW Lower Subansiri HEP is among the largest of Arunachal's 160+ hydropower projects to be constructed on various tributaries of the Brahmaputra river. While most of these projects cause only limited displacement in sparsely populated Arunachal, the strongest resistance has come from civil society and political groups in downstream Assam, a densely populated state occupying the Brahmaputra floodplains. Conflict over Lower Subansiri started in the early 2000s. River-dependent communities in Assam were concerned about the dam impacting river flows and the floodplain ecology - livelihood base for a vast, rural population. They were also familiar with the dams' unintended, incalculable and uninsurable risks. The collective memory of the 1950 Assam earthquake, when the failure of a natural landslide dam on the Subansiri river caused catastrophic floods is still strong [101]. Since 2004, floods have been aggravated repeatedly by sudden excessive releases of water from hydropower projects in Arunachal Pradesh, Bhutan and Nagaland [27,102]. However, 
since Indian environmental policy includes no mechanism to account for downstream impacts of large dams, downstream-affected people were systematically excluded from negotiations over rehabilitation and benefit-sharing.

By 2006, an alliance of affected people and local student unions succeeded in pressuring the Government of Assam to commission a downstream impact study, conducted by an interdisciplinary eight-member expert committee from reputed Assamese universities. Their report, completed in 2010, gave scientific endorsement to the activists' concerns: operating the dam would cause dramatic daily flow fluctuations to be felt for hundreds of kilometers downstream. Another alarming discovery were flaws in the seismic-geological aspects of the project. Despite poor geological conditions and a highly earthquake-prone location, NHPC had made several modifications to the dam's original design parameters, which would reduce the costs of the project but increase its risks -including reducing the width and depth of the foundation, shifting the powerhouse underground, choosing concrete over rock-fill technology, and minimizing the project's flood cushion. The report triggered massive public support and the formation of a mass movement comprising affected communities, student and farmer organizations, and the state's major opposition party. In 2011, a road blockade temporarily shut down construction works. The project has remained suspended ever since.

The expert committee suggested to simply change the dam's design parameters. But NHPC, possibly concerned about additional costs and its reputation, mobilized its own group of experts from reputed national scientific institutions (some of whom had helped design and clear the project in the first place) to delegitimize the concerns raised against the dam and the validity of the claims by the Assamese experts [101]. This led to a highly politicized stand-off between the corporation and the movement and a more ambiguous group of national and regional politicians, bureaucrats and scientists between the two ends of the spectrum.

The government, responsible to take a final call on the fate of the project has since been under immense political pressure from both sides. The stakes are high: huge financial losses for NHPC; sacrifices in voter numbers; and powerful political interests at national level. Moreover, this being the first successful large-scale anti-dam protest of downstream communities in India, the decision will set an important precedent for hydropower conflicts in the country. Thus, instead of taking a clear stand on the issue, the state government has delegated expert committee after expert committee, each time engaging more senior and "qualified" experts, in hope of obtaining unambiguous evidence on the safety of the dam.

The effect has been the opposite: each round of expert scrutiny has not only revalidated the technical concerns already raised, but also revealed others. It has also made visible that science is not isolated from political pressures. The penultimate expert committee produced four Assamese votes against the dam and four votes by Central Government-appointed non-Assamese experts in favor [103]. Likewise, the latest expert-panel appointed by the MoEF stands accused of a possible conflict of interest, since its three members belong to institutions backing NHPC's position on the project in the past [104].

\section{Discussion: Challenging the Production of Unequal Risk through Knowledge Co-Production}

With this paper I have sought to explain why considerations of hazard potential and dam safety occupy a marginal position in the governance of Himalayan hydropower projects and their contestation, and how this contributes to the material production of uneven risks and vulnerabilities in hydropower-producing areas. My main analytical focus has been on two arenas of environmental governance: institutional mechanisms and knowledge politics.

While research on uneven geographies of risk has focused on the role of techno-scientific representations in shaping knowledge about risk [33-35], the findings from Sikkim point to a different type of knowledge politics: to legitimize complacency in the face of heightened hazard potential, the question of risk is discursively and institutionally erased and invisibilized. This "environmental denial" [24] (p. 15) by members of Sikkim's hydropower community (and beyond Sikkim [28,32,79]) 
is facilitated by various types of uncertainty, related for example to the invisibility of large parts of the project infrastructure, the difficulty to expose below-ground hydrogeological processes, or the impossibility to predict future hydro-climatic hazards. Expert discourses and political decision-makers selectively mobilize these uncertainties, but also actively reinforce them, by discrediting alternative sources of knowledge and by influencing what type of knowledge is produced.

These insights speak to a community of research on the deliberate production, perpetuation and institutionalization of ignorance and scientific ambiguity-also referred to as agnotology, antiepistemology, or the strategic unknowns, among others [32,54,105]. Ignorance studies explore the use of ignorance as a resource to deflect, obscure, conceal or magnify knowledge that is dangerous or unpalatable to powerful interest groups [32,55], and fill an important theoretical void: they account for absences in knowledge production—knowledge, which gets lost or never gets made [39,106,107]—and counter the common assumption that knowledge is necessarily more powerful than ignorance [32,55]. As McGoey [32] (p. 5) argues,

"We need less attention to the politics of knowledge and more to the politics of ignorance, to the mobilization of ambiguity, the denial of unsettling facts, the realization that knowing the least amount possible is often the most indispensable tool for managing risks and exonerating oneself from blame in the aftermath of catastrophic events."

In Sikkim, institutionalized ignorance about certain hydropower risks and impacts has enabled the unchecked construction of hazardous hydropower projects. Further, by undermining the assessment, prevention and mitigation of hydropower risks, it has helped to maintain uncertainty, obscure liabilities, and thus prevent policy amendments and other changes in the official "rules of the game", which could jeopardize the viability of hydropower investments and investment decisions. For example, establishing liabilities in the EIA or adjusting environmental clearance requirements would imply lengthier, more elaborate, and more costly clearance procedures. Obliging developers to acquire all land and rehabilitate all households physically impacted during the entire project cycle would make project costs spiral. Such measures could also increase the likelihood of (organized) resistance by affected communities, implying further delays and expenses.

Admittedly, the strategicness of ignorance about hydropower risks in Sikkim is debatable. As McGoey [55] argues, the power and success of ignorance is underpinned by the difficulty "of proving whether someone is actually ignorant or simply feigning ignorance" (p. 559). In the Himalayas, geological and seismic uncertainty and the unpredictability of certain earth system dynamics complicate the question of strategic ignorance. Rather than a "deliberately wielded tool", could ignorance here also simply be "an unavoidable handicap" (ibid.)? I would argue that deliberation becomes evident when one looks beyond what experts, hydropower professionals and decision-makers claim not to know, and at how they deal with risk and uncertainty. Rather than improving the state of knowledge and applying double precautionary measures, Sikkim's hydropower community has used ignorance as an excuse not to act. Whether this "blissful disinterest" is strategy or merely convenience, the lack of preparation it imposes on the state and its population is hard to justify. As the editor of a prominent local newspaper argues about Sikkim's disaster management culture:

"Unprepared, is inexcusable for a population that has lived with slides and shakes since forever and specially not at this juncture when there is (...) a full-fledged department for Disaster Risk Management and earmarked funds as well. How can any area in Sikkim not have a risk reduction plan to limit the damage caused by landslides and earthquakes? ( . . ) Unless one understands the causes, how can safeguards against such disasters in the future be devised? Preparation requires accepting that a threat exists and then understanding the reasons causing (it)" [108].

Further, this paper has shown institutionalized ignorance to be a central mechanism in relational processes of marginalization and facilitation, allowing for the material production and shifting 
of risk [33-35,52]. Investment incentives have encouraged a hydropower development model, which diverts public resources for private profit and consumption elsewhere, while externalizing environmental risks and costs, thus compromising on factors of socio-environmental impact and structural safety. The exclusion of certain risks from impact assessment and rehabilitation processes has jeopardized households and entire communities, up to the point of unforeseen displacement. The failure to investigate and communicate the causes of incurred damages has obscured the question of liability. Depriving affected communities of systematic, adequate and timely rehabilitation, and undermining the ability of state institutions, communities and households to anticipate and adapt to risk situations has exacerbated vulnerabilities and deepened social marginalization.

Clearly, marginalization and facilitation go hand in hand here: while the risks produced through strategic ignorance threaten the lives, livelihoods and living environments of people in hydropower-producing areas, they represent economic opportunities for powerful corporate and political interest groups. Not surprisingly, the latter are actors usually far removed from these local realities, indicating how the production of geographically and racially uneven hazardscapes perpetuates historical patterns of dependency and exploitation between the Indian state and its margins, but also within frontier spaces like Sikkim [25].

Finally, this paper has drawn on two different case studies to understand what determines compliance and resistance to the production and discursive erasure of risk. The Sikkim case study illustrates that institutionalized ignorance, which instrumentalizes scientific uncertainty is a challenge to public resistance. As Butler and Rest observed in Nepal, laypeople often "cannot marshal an opposition to dam construction ( . . . ) beyond supposition [and] having little evidence for their position, (... ) can only warn about the danger of dam breach as a possibility rather than a likelihood" [24] (p. 23). The Assamese resistance against the Lower Subansiri dam is instructive because it has managed to overcome this challenge. While the impetus for public concern came from embodied experiential knowledge, based on the lived memories of flood disasters, the movement has successfully mobilized the epistemic authority of scientific experts to expose the malleability of science and to stake alternative claims about the dam's risks. This public contestation of the risk question has been so powerful that it has caught political decision-makers at state and national level in a bind for nearly a decade.

But how useful is the Assamese experience for those affected by risky dam construction in Sikkim? No doubt, troubled state-society relations complicate the question of resistance in Sikkim, where political pressure and authoritarian government tendencies have long curtailed opportunities for affected communities and civil society groups to challenge development decisions [11]. Interviews in project-affected areas produced multiple accounts of repressive tactics used by project developers and state authorities in response to individual complaints and collective protests, creating widespread fear of dissent. Likewise, several respondents from NGOs explained that they must take a politically neutral stand and cannot work "against the government" for fear of political retaliation. As a result, hardly any environmental NGOs or research organizations in Sikkim are willing to openly engage with hydropower development.

Moreover, questions of ethnic identity and minority politics have historically fractured social mobilization in the state. Like other states of Northeast India, Sikkim's population comprises of numerous ethnic groups, who compete for access to public resources through reservations [109]. While Assam is no less tormented by ethnic politics, the activists have not framed their struggle in ethnic-cultural terms. Unlike in Sikkim, Assamese activists could draw on a powerful culture of class-based resistance and a long history of peasant and student mobilization to build strength in numbers [110,111]. Thus, resistance, which initially emerged in response to individual dam projects eventually turned into a state-wide movement against dam construction on the Brahmaputra River.

It is doubtful whether such a mass movement, articulated in terms of environmental justice could ever materialize in Sikkim. And in fact, this is not to downplay the remarkable successes Sikkimese anti-dam movements have achieved by using ethnic and cultural particularism as mobilizing concepts because they do carry political clout. These achievements deserve greater recognition, as I have argued 
elsewhere [112]. Nevertheless, to resist "unavoidable externalities" like heightened ecological precarity, disaster risk and social marginalization by projects yet to be built/completed, the Subansiri case does provide a useful lesson: the power to define risks and their acceptability is not entirely monopolized by experts. Hegemonic expert discourses can be punctured and subverted, particularly when they bank on contested knowledges [62]. The activists in Assam have achieved this by entering the field of knowledge production and bridging the lay-expert divide [101].

More generally, the successful challenge this citizen-science alliance has mounted against institutionalized ignorance testifies to the need for a democratization of knowledge production: reconsidering the exclusive authority awarded to experts, and recognizing the value and particularity of the embodied, experiential knowledge, which comes from having to live with ecological precarity [25]. As experiences of human-made, capital-driven disasters-many dam accidents included-indicate, scientific controversies often come to light only in the aftermath of catastrophe, while public resistances based on experiential knowledge of the local climate, geology, hydrology, and disaster historiography can issue effective early warnings [6]. Such contestations therefore deserve more credence by environmental decision-makers, especially for complex governance problems with high political stakes and high uncertainty.

There are already multiple proposals for the co-production of knowledge out there, including post-normal science [113], citizen science [114], street science [115], or activism mobilizing science [116], among others. These approaches center on inclusive strategies, seeing citizens not "as passive receivers [but] as active partners in the production of knowledge" [59] (p. 71), and have proven particularly useful for environmental justice conflicts with uncertain facts, disputed values, high stakes and urgently required decisions [113]. By establishing new linkages between experts/science and citizens/activism, and by promoting alternative perspectives, knowledge co-production frameworks counter the technocratization and scientization of knowledge production [59], and the instrumentalization of scientific complexity and uncertainty for political purposes.

Despite the constrained political space for hydropower activism, Sikkim has potential for creating such citizen-science linkages. First, as mentioned earlier, local knowledge is already consulted and put to use in different development and environmental research initiatives [29,95-97], demonstrating a general appreciation of vernacular perspectives. Second, as this paper has demonstrated, not all experts are complicit in invisibilizing risk and in ridiculing vernacular perspectives. Many government and NGO-experts work closely with local communities, and given the limited influence regional state agencies have on hydropower governance decisions, some experts have openly professed their antagonistic relationship with hydropower developers and their disdain for corporate negligence in environmental management, siding with locals instead [25]. Finally, with Indian environmental activism shifting increasingly to the legal level, civil society groups may be able to push for improvements in the implementation of participatory tools, such as the EIA process or the veto power of the gram sabhas (village assemblies), which are explicitly designed to broaden the knowledge base for governance decisions by including local perspectives.

Nevertheless, to create powerful citizen-science linkages and mobilize Sikkim's extensive environmental research community, concerned scientists and other experts in the state must leave the comfort of alleged objectivity and challenge the power structures, which influence what environmental knowledge may be produced or not. Sikkim's contested hydropower future and its environmental ramifications are after all not technical, but fundamentally political questions, and engaging with or abstaining from these is a fundamentally political choice.

In closing, I want to point to three specific policy implications of strategic and institutionalized ignorance in the hydropower sector, particularly in a context of climate change. First, there clearly is an urgent need to reevaluate the viability and hazard vulnerability of Himalayan hydropower infrastructure. The latter has a significant bearing on the economic potential of new hydropower ventures, too, and for decision-making on future development pathways of Himalayan constituencies [24,74]. 
Second, as this paper has illustrated, hydropower infrastructure and its neglectful governance can exacerbate climate vulnerability and complicate adequate climate action. Framing hydropower as a climate mitigating energy technology without due attention to associated risks is misleading and leads to maladaptation [117].

Finally, as Lord [57] suggests, with more powerful natural hazards to be expected in mountain regions around the world, and given the significant uncertainties over the looming impacts of climate change, the time seems ripe to take seriously "technologies of humility", such as micro-hydropower and other decentralized renewable solutions, and to dismiss the infrastructural hubris which has long driven risky hydropower investments.

Funding: This research was funded by the European Union's Seventh Framework Programme for research, technological development and demonstration (Marie Curie Actions) grant number 289374 ("ENTITLE").

Acknowledgments: The author would like to thank Begüm Özkaynak, Giorgos Kallis, Mabel Gergan, Austin Lord, Santiago Gorostiza, Manish Kumar, the editors of this special issue, and two anonymous reviewers for their constructive comments on earlier versions of this article. My gratitude also goes to Samuel Thomas, Partha J. Das and K. J. Joy for their invaluable guidance and support while undertaking fieldwork, as well as to Anuradha Bhutia, Sweekriti Pradhan, Prerana Nair and Shubhangi Shukla for research assistance.

Conflicts of Interest: The author declares no conflict of interest. The funders had no role in the design of the study; in the collection, analyses, or interpretation of data; in the writing of the manuscript, and in the decision to publish the results.

\section{References}

1. Ives, M. A Day Before Laos Dam Failed, Builders Saw Trouble. 2018. Available online: https://www.nytimes. com/2018/07/26/world/asia/laos-dam-collapse.html (accessed on 31 July 2018).

2. Thakkar, H. Role of dams in Kerala's flood disaster. Econ. Polit. Wkly. 2018, LIII, 20-23.

3. McCully, P. Silenced Rivers: The Ecology and Politics of Large Dams; Zed Books: London, UK, 2001; ISBN 978-1-85649-901-9.

4. Pearce, F. The Dammed: Rivers, Dams, and the Coming World Water Crisis; Bodley Head: London, UK, 1992; ISBN 978-0-370-31609-3.

5. Armiero, M. A Rugged Nation: Mountains and the Making of Modern Italy; The Whitehorse Press: Cambridge, UK, 2011.

6. Huber, A.; Gorostiza, S.; Kotsila, P.; Beltrán, M.J.; Armiero, M. Beyond "socially constructed" disasters: Re-politicizing the debate on large dams through a political ecology of risk. Capital. Nat. Social. 2017, 28, 48-68. [CrossRef]

7. Ahlers, R.; Budds, J.; Joshi, D.; Merme, V.; Zwarteveen, M. Framing hydropower as green energy: Assessing drivers, risks and tensions in the Eastern Himalayas. Earth Syst. Dyn. 2015, 6, 195-204. [CrossRef]

8. Ahlers, R.; Zwarteveen, M.; Bakker, K.; Flyvbjerg, B. Large Dam Development: From Trojan Horse to Pandora's Box. In The Oxford Handbook of Megaproject Management; Flyvbjerg, B., Ed.; OUP: Oxford, UK, 2017.

9. Lord, A. Citizens of a hydropower nation: Territory and agency at the frontiers of hydropower development in Nepal: Nepalese hydropower development. Econ. Anthropol. 2016, 3, 145-160. [CrossRef]

10. Schneider, H. World Bank Turns to Hydropower to Square Development with Climate Change. 2013. Available online: https://www.washingtonpost.com/business/economy/world-bank-turnsto-hydropower-to-square-development-with-climate-change/2013/05/08/b9d60332-b1bd-11e2-9a984be1688d7d84_story.html (accessed on 31 July 2018).

11. Huber, A.; Joshi, D. Hydropower, anti-politics, and the opening of new political spaces in the eastern Himalayas. World Dev. 2015, 76, 13-25. [CrossRef]

12. Zarfl, C.; Lumsdon, A.E.; Berlekamp, J.; Tydecks, L.; Tockner, K. A global boom in hydropower dam construction. Aquat. Sci. 2015, 77, 161-170. [CrossRef]

13. Mukerjee, M. The Impending Dam Disaster in the Himalayas. 2015. Available online: https://www. scientificamerican.com/article/the-impending-dam-disaster-in-the-himalayas/ (accessed on 1 August 2018).

14. Merme, V.; Ahlers, R.; Gupta, J. Private equity, public affair: Hydropower financing in the Mekong Basin. Glob. Environ. Chang. 2014, 24, 20-29. [CrossRef] 
15. Parry, M.L.; Canziani, O.F.; Palutikof, J.P.; van der Linden, P.J.; Hanson, C.E. IPCC 2007. Climate Change 2007: Impacts, Adaptation and Vulnerability; Cambridge University Press: Cambridge, UK; New York, NY, USA, 2007.

16. Tse-ring, K.; Sharma, E.; Chettri, N.; Shrestha, A. Climate Change Vulnerability of Mountain Ecosystems in the Eastern Himalayas; ICIMOD Books; ICIMOD: Kathmandu, Nepal, 2010; ISBN 978-92-9115-142-4.

17. Kelly-Richards, S.; Silber-Coats, N.; Crootof, A.; Tecklin, D.; Bauer, C. Governing the transition to renewable energy: A review of impacts and policy issues in the small hydropower boom. Energy Policy 2017, 101, 251-264. [CrossRef]

18. Grumbine, R.E.; Pandit, M.K. Threats from India's Himalaya dams. Science 2013, 339, 36-37. [CrossRef] [PubMed]

19. Winemiller, K.O.; McIntyre, P.B.; Castello, L.; Fluet-Chouinard, E.; Giarrizzo, T.; Nam, S.; Baird, I.G.; Darwall, W.; Lujan, N.K.; Harrison, I.; et al. Balancing hydropower and biodiversity in the Amazon, Congo, and Mekong. Science 2016, 351, 128-129. [CrossRef] [PubMed]

20. Chettri, M. Ethnic environmentalism in the eastern Himalaya. Econ. Polit. Wkly. 2017, LII, 34-40.

21. Gergan, M.D. Living with earthquakes and angry deities at the Himalayan borderlands. Ann. Am. Assoc. Geogr. 2017, 107, 490-498. [CrossRef]

22. Kohli, K. Inducing vulnerabilities in a fragile landscape. Econ. Polit. Wkly. 2011, 19-22.

23. Rampini, C. Impacts of Hydropower Development along the Brahmaputra River in Northeast India on the Resilience of Downstream Communities to Climate Change Impacts. Ph.D. Thesis, University of California, Santa Cruz, CA, USA, 2016.

24. Butler, C.; Rest, M. Calculating risk, denying uncertainty: Seismicity and hydropower development in Nepal. HIMALAYA J. Assoc. Nepal Himal. Stud. 2017, 37, 6.

25. Gergan, M.D. Precarity and Possibility at the Margins: Hazards, Infrastructure, and Indigenous Politics in Sikkim, India. Ph.D. Thesis, The University of North Carolina at Chapel Hill, Chapel Hill, NC, USA, 2016.

26. Kumar, D.; Katoch, S.S. Dams turning devils: An insight into the public safety aspects in operational run of the river hydropower projects in western Himalayas. Renew. Sustain. Energy Rev. 2017, 67, 173-183. [CrossRef]

27. Vagholikar, N.; Das, P.J. Damming Northeast India; Kalpavriksh, Aaranyak, and Action Aid India: Pune, India, 2010.

28. Lord, A. Speculation and seismicity: Reconfiguring the hydropower future in post-earthquake Nepal. In Water, Technology, and the Nation-State; Menga, F., Swyngedouw, E., Eds.; Routledge: Oxon, UK, 2018.

29. Government of Sikkim. Sikkim State Action Plan on Climate Change (2012-2030); Government of Sikkim: Gangtok, India, 2014.

30. State Disaster Management Authority. Sikkim State Disaster Management Plan; State Disaster Management Authority, Government of Sikkim: Gangtok, India, 2015.

31. Government of Sikkim Forests, Environment \& Wildlife Management Department I Environment. Available online: http:/ / www.sikkimforest.gov.in/environment.htm\#eia (accessed on 1 August 2018).

32. McGoey, L. Strategic unknowns: Towards a sociology of ignorance. Econ. Soc. 2012, 41, 1-16. [CrossRef]

33. Collins, T.W. The production of unequal risk in hazardscapes: An explanatory frame applied to disaster at the US-Mexico border. Geoforum 2009, 40, 589-601. [CrossRef]

34. Fraser, A. The missing politics of urban vulnerability: The state and the co-production of climate risk. Environ. Plan. A 2017, 49, 2835-2852. [CrossRef]

35. Mustafa, D. The production of an urban hazardscape in Pakistan: Modernity, vulnerability, and the range of choice. Ann. Assoc. Am. Geogr. 2005, 95, 566-586. [CrossRef]

36. Pelling, M. The political ecology of flood hazard in urban Guyana. Geoforum 1999, 30, 249-261. [CrossRef]

37. Davis, M. Ecology of Fear: Los Angeles and the Imagination of Disaster; Metropolitan Books: New York, NY, USA, 1998.

38. Boelens, R.; Shah, E.; Bruins, B. Contested Knowledges: Large Dams and Mega-Hydraulic Development. Water 2019, 11, 416. [CrossRef]

39. Frickel, S. On missing New Orleans: Lost knowledge and knowledge gaps in an urban hazardscape. Environ. Hist. 2008, 13, 643-650.

40. Michaels, D.; Monforton, C. Manufacturing uncertainty: Contested science and the protection of the public's health and environment. Am. J. Public Health 2005, 95, 39-48. [CrossRef] [PubMed] 
41. Hewitt, K. (Ed.) Interpretations of Calamity from the Viewpoint of Human Ecology; Allen \& Unwin: Boston, MA, USA, 1983.

42. O'Keefe, P.; Westgate, K.; Wisner, B. Taking the naturalness out of disasters. Nature 1976, 260, $566-567$. [CrossRef]

43. Waddell, E. The hazards of scientism: A review article. Hum. Ecol. 1977, 5, 69-76. [CrossRef]

44. Wisner, B.; Blaikie, P.; Cannon, T.; Davis, I. At Risk: Natural Hazards, Peoples Vulnerability; Routledge: London, UK, 2004.

45. Beck, U. World at Risk, 2nd ed.; Polity Press: Cambridge, UK, 2009.

46. Baldwin, A.; Stanley, A. Risky natures, natures of risk. Geoforum 2013, 45, 2-4. [CrossRef]

47. Wisner, B. Business-as-usual disaster relief. Capital. Nat. Social. 2012, 23, 123-128. [CrossRef]

48. Freudenburg, W.R.; Gramling, R.; Laksa, S.; Erikson, K.T. Organizing hazards, engineering disasters? Improving the recognition of political-economic factors in the creation of disasters. Soc. Forces 2008, 87, 1015-1038. [CrossRef]

49. Clarke, L. Postscript: Considering katrina. In The Sociology of Katrina: Perspectives on a Modern Catastrophe; Brunsma, D.L., Overfelt, D., Picou, J.S., Eds.; Rowman \& Littlefield: Lanham, MD, USA, 2007; pp. 235-242, ISBN 978-0-7425-5930-1.

50. Davis, H.; Todd, Z. On the importance of a date, or decolonizing the anthropocene. ACME Int. J. Crit. Geogr. 2017, 16, 761-780.

51. Tognetti, S.S. Revisiting Post-Normal Science in Post-Normal Times \& Identifying Cranks. 2013. Available online: http:/ / www.postnormaltimes.net/wpblog/revisiting-post-normal-science-in-post-normal-timesidentifying-cranks / (accessed on 1 August 2018).

52. Stanley, A. Natures of risk: Capital, rule, and production of difference. Geoforum 2013, 45, 5-16. [CrossRef]

53. Woodhouse, E.; Hess, D.; Breyman, S.; Martin, B. Science studies and activism: Possibilities and problems for reconstructivist agendas. Soc. Stud. Sci. 2002, 32, 297-319. [CrossRef]

54. Proctor, R.N.; Schiebinger, L. (Eds.) Agnotology: The Making and Unmaking of Ignorance; Stanford University Press: Stanford, CA, USA, 2008. [CrossRef]

55. McGoey, L. The logic of strategic ignorance. Br. J. Sociol. 2012, 63, 533-576. [CrossRef] [PubMed]

56. Oreskes, N.; Conway, E.M. Merchants of Doubt; Bloomsbury: London, UK, 2010.

57. Lord, A. Humility and hubris in hydropower. Limn 2017, 9. Available online: https://limn.it/articles/ humility-and-hubris-in-hydropower/ (accessed on 1 August 2018).

58. Gramsci, A. Selections from the Prison Notebooks; International Publishers: New York, NY, USA, 1971.

59. Lidskog, R. Scientised citizens and democratised science. Re-assessing the expert-lay divide. J. Risk Res. 2008, 11, 69-86. [CrossRef]

60. Beck, U. Risk Society: Towards a New Modernity; Theory, culture \& society; Sage Publications: London, UK, 1992; ISBN 978-0-8039-8345-8.

61. Finger, Y.; Jebri, L.; Kühne, F.; Scheffel, L.; Schnippe, M. Politicisation of science in the process of dealing with manufactured risk. MaRBLe 2016, 4. [CrossRef]

62. Cooper, T.; Bulmer, S. Refuse and the "risk society": The political ecology of risk in inter-war Britain. Soc. Hist. Med. 2013, 26, 246-266. [CrossRef] [PubMed]

63. Maeseele, P. On neo-luddites led by ayatollahs: The frame matrix of the GM food debate in northern Belgium. Environ. Commun. 2010, 4, 277-300. [CrossRef]

64. Whatmore, S.J. Mapping knowledge controversies: Science, democracy and the redistribution of expertise. Prog. Hum. Geogr. 2009, 33, 587-598. [CrossRef]

65. Saitta, P.; Lazzerini, I. Environment and the citizens: Popular struggles, popular epidemiology, and other forms of resistance "from below" in areas at risk worldwide-An introduction. Capital. Nat. Social. 2015, 26, 35-38. [CrossRef]

66. Hewitt, K.; Mehta, M. Rethinking risk and disasters in mountain areas. J. Alp. Res. Rev. Géogr. Alp. 2012. [CrossRef]

67. Pandit, M.K.; Manish, K.; Koh, L.P. Dancing on the roof of the world: Ecological transformation of the Himalayan landscape. BioScience 2014, 64, 980-992. [CrossRef]

68. Lutz, A.F.; Immerzeel, W.W.; Shrestha, A.B.; Bierkens, M.F.P. Consistent increase in high Asia's runoff due to increasing glacier melt and precipitation. Nat. Clim. Chang. 2014, 4, 587. [CrossRef] 
69. Nepal, S.; Shrestha, A.B. Impact of climate change on the hydrological regime of the Indus, Ganges and Brahmaputra river basins: A review of the literature. Int. J. Water Resour. Dev. 2015, 31, 201-218. [CrossRef]

70. Shrestha, U.B.; Gautam, S.; Bawa, K.S. Widespread climate change in the Himalayas and associated changes in local ecosystems. PLoS ONE 2012, 7, e36741. [CrossRef] [PubMed]

71. Shrestha, B.; Mool, P.K.; Bajracharya, S.R. Impact of Climate Change on Himalayan Glaciers and Glacial Lakes: Case Studies on GLOF and Associated Hazards in Nepal and Bhutan; International Centre for Integrated Mountain Development (ICIMOD); United Nations Environment Programme (UNEP): Kathmandu, Nepal, 2007; ISBN 978-92-9115-032-8.

72. Chopra, R.; Das, B.P.; Dhyani, H.; Verma, A.; Venkatesh, H.S.; Vasistha, H.B.; Dobhal, D.P.; Juyal, N.; Sathyakumar, S.; Pathak, S.; et al. Assessment of Environmental Degradation and Impact of Hydroelectric Projects during the June 2013 Disaster in Uttarakhand; The Ministry of Environment and Forests, Government of India: New Delhi, India, 2014.

73. Poudel, R.R. Sunkoshi Dam Weakened by August Flood, Landslide. Available online: http:/ / kathmandupost. ekantipur.com/news/2014-09-18/sunkoshi-dam-weakened-by-august-flood-landslide.html (accessed on 2 August 2018).

74. Schwanghart, W.; Ryan, M.; Korup, O. Topographic and seismic constraints on the vulnerability of Himalayan hydropower. Geophys. Res. Lett. 2018, 45, 8985-8992. [CrossRef]

75. Schwanghart, W.; Worni, R.; Huggel, C.; Stoffel, M.; Korup, O. Uncertainty in the Himalayan energy-water nexus: Estimating regional exposure to glacial lake outburst floods. Environ. Res. Lett. 2016, 11, 074005. [CrossRef]

76. Nixon, R. Slow Violence and the Environmentalism of the Poor; Harvard University Press: Cambridge, CA, USA, 2011; ISBN 978-0-674-04930-7.

77. Drew, G. Mountain women, dams, and the gendered dimensions of environmental protest in the Garhwal Himalaya. Mt. Res. Dev. 2014, 34, 235-242. [CrossRef]

78. Erlewein, A.; Nüsser, M. Offsetting greenhouse gas emissions in the Himalaya? Clean development dams in Himachal Pradesh, India. Mt. Res. Dev. 2011, 31, 293-304. [CrossRef]

79. Buechler, S.; Sen, D.; Khandekar, N.; Scott, C. Re-linking governance of energy with livelihoods and irrigation in Uttarakhand, India. Water 2016, 8, 437. [CrossRef]

80. Manish, S. A Paradise Dammed. 2011. Available online: http://archive.tehelka.com/story_main50.asp? filename=Ne081011PARADISE.asp (accessed on 2 August 2018).

81. Lepcha, T. Chungthang-The Kalapani of the 21st Century. Available online: http://www.actsikkim.com/ docs/Press_Release_Chungthang_EQ.pdf (accessed on 2 August 2018).

82. Mazoomdaar, J. In fact: And the Rivers be Dammed. Indian Express 2016. Available online: https:// indianexpress.com/article/explained/kedarnath-uttarakhand-floods-garhwal-earthquake-2867742/ (accessed on 1 August 2018).

83. Dharmadikary, S. Mountains of Concrete: Dam Building in the Himalayas; International Rivers: Berkeley, CA, USA, 2008.

84. WCD. Dams and Development: A New Framework for Decision-Making: The Report of the World Commission on Dams; Earthscan: London, UK, 2000; ISBN 978-1-85383-798-2.

85. Moore, D.; Dore, J.; Gyawali, D. The world commission on dams + 10: Revisiting the large dam Controversy. Water Altern. 2010, 3, 11.

86. Wangchuk, P.D. Sikkim's Hydel Story: The Journey from $50 \mathrm{KW}$ in 1927, $30 \mathrm{MW}$ in 1994, to 2200 MWs in 2018. Available online: https:/ / www.summittimes.com/single-post/2018/04/04/Sikkim\%E2\%80\%99s-Hydel-StoryThe-journey-from-50KW-in-1927-30MW-in-1994-to-2200-MWs-in-2018 (accessed on 2 August 2018).

87. Bhattacharjee, U. Dam Planning Under the Spotlight: A Guide to Dam Sanctioning in India; International Rivers: Berkeley, CA, USA, 2013.

88. Energy and Power Department. Energy and Power Sector Vision 2015; Government of Sikkim: Gangtok, India, 2010.

89. Joshi, D. Like water for justice. Geoforum 2015, 61, 111-121. [CrossRef]

90. Hill, D.P. Where Hawks Dwell on water and bankers build power poles: Transboundary waters, environmental security and the frontiers of neo-liberalism. Strateg. Anal. 2015, 39, 729-743. [CrossRef] 
91. Rahman, M.Z. Territory, Tribes, Turbines: Local Community Perceptions and Responses to Infrastructure Development along the Sino-Indian Border in Arunachal Pradesh; Institute of Chinese Studies: New Delhi, India, 2014; Volume 7.

92. Alley, K.D.; Hile, R.; Mitra, C. Visualizing hydropower across the Himalayas: Mapping in a time of regulatory decline. HIMALAYA J. Assoc. Nepal Himal. Stud. 2014, 34, 17.

93. Vagholikar, N. Risks without enough gain. Telegr. India 2007. Available online: http://weepingsikkim. blogspot.it/2007/12/risks-without-enough-gain.html (accessed on 27 August 2013).

94. Sharma, A.; Sherpa, N.; Lepcha, G.T.; Luitel, K.K. Report on Damages Caused Due to Tunnel Excavation and Other Activities under Teesta-Hydro-Electric Project Stage V; Department of Mines, Minerals \& Geology, Government of Sikkim: Gangtok, India, 2010.

95. Chaudhary, P.; Bawa, K.S. Local perceptions of climate change validated by scientific evidence in the Himalayas. Biol. Lett. 2011, 7, 767-770. [CrossRef] [PubMed]

96. Tambe, S.; Arrawatia, M.L.; Bhutia, N.T.; Swaroop, B. Rapid, cost-effective and high resolution assessment of climate-related vulnerability of rural communities of Sikkim Himalaya, India. Curr. Sci. 2011, 101, 9.

97. Tambe, S.; Kharel, G.; Arrawatia, M.L.; Kulkarni, H.; Mahamuni, K.; Ganeriwala, A.K. Reviving dying springs: Climate change adaptation experiments from the Sikkim Himalaya. Mt. Res. Dev. 2012, 32, 62-72. [CrossRef]

98. Anderson, P.N. The GE Debate: What is at risk when risk is defined for us? Capital. Nat. Social. 2001, 12, 39-44. [CrossRef]

99. Swyngedouw, E. Impossible "sustainability" and the postpolitical condition. In The Sustainable Development Paradox: Urban Political Economy in the United States and Europe; Krueger, R., Gibbs, D., Eds.; Guilford Press: New York, NY, USA, 2007; pp. 13-40. ISBN 978-1-59385-498-0.

100. Maeseele, P. The risk conflicts perspective: Mediating environmental change we can believe in. Bull. Sci. Technol. Soc. 2015, 35, 44-53. [CrossRef]

101. Baruah, S. Whose river is it anyway? Political economy of hydropower in the Eastern Himalayas. Econ. Polit. Wkly. 2012, XLVII, 41-52.

102. Chakravartty, A. Thousands Marooned in a "Dam-Induced" Flood in Golaghat. 2018. Available online: https: / / www.downtoearth.org.in/news/thousands-marooned-in-a-dam-induced-flood-in-golaghat61326 (accessed on 2 August 2018).

103. Sengupta, A. Assam experts wary of dam renewal-Call solve seismic, geological issues. Telegraph, 2016. Available online: https://www.telegraphindia.com/1160312/jsp/frontpage/story_74100.jsp (accessed on 2 August 2018).

104. Mukul, J.; Jai, S. NHPC's “Biggest” Subansiri Hydropower Project Stalled on Panel Names. 2018. Available online: https: / / www.business-standard.com/article/economy-policy/nhpc-s-subansiri-project-stalledover-composition-of-expert-committee-118080201217_1.html (accessed on 2 August 2018).

105. Galison, P. Removing knowledge. Crit. Inq. 2004, 31, 229-243. [CrossRef]

106. Frickel, S.; Vincent, M.B. Hurricane katrina, contamination, and the unintended organization of ignorance. Technol. Soc. 2007, 29, 181-188. [CrossRef]

107. Frickel, S. Absences: Methodological note about nothing, in particular. Soc. Epistemol. 2014, 28 , 86-95. [CrossRef]

108. Summit TIMES. Editorial: Sensitive to Disasters. 2018. Available online: https:/ /www.summittimes.com/ single-post/2018/10/04/Editorial-Sensitive-to-Disasters (accessed on 10 October 2018).

109. Chettri, M. Ethnicity and Democracy in the Eastern Himalayan Borderland: Constructing Democracy; Amsterdam University Press: Amsterdam, The Netherlands, 2017; ISBN 978-90-485-2750-2.

110. Saikia, A. A Century of Protests: Peasant Politics in Assam Since 1900; Routledge: New Delhi, India, 2014; ISBN 978-1-317-32559-8.

111. Baruah, M. Suffering for Land: Environmental Hazards and Popular Struggles in the Brahmaputra Valley (Assam), India. Ph.D. Thesis, Syracuse University, Syracuse, NY, USA, 2016.

112. Huber, A.; Joshi, D. Hydropower conflicts in Sikkim: Recognizing the power of citizen initiatives for socio-environmental justice. In Water Conflicts in Northeast India; Joy, K.J., Das, P.J., Chakraborty, G., Mahanta, C., Paranjape, S., Vispute, S., Eds.; Routledge: Oxon, UK, 2018; pp. 71-91, ISBN 978-1-351-68594-8.

113. Funtowicz, S.O.; Ravetz, J.R. Uncertainty, complexity and post-normal science. Environ. Toxicol. Chem. 1994, 13, 1881-1885. [CrossRef] 
114. Irwin, A. Citizen Science: A Study of People, Expertise and Sustainable Development; Routledge: Oxon, UK, 1995.

115. Corburn, J. Street Science: Community Knowledge and Environmental Health Justice; MIT Press: Cambridge, MA, USA, 2005; ISBN 978-0-262-53272-3.

116. Conde, M. Activism mobilising science. Ecol. Econ. 2014, 105, 67-77. [CrossRef]

117. Barnett, J.; O’Neill, S. Maladaptation. Glob. Environ. Chang. 2010, 20, 211-213. [CrossRef]

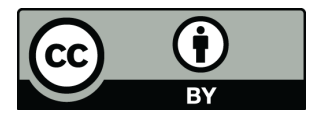

(C) 2019 by the author. Licensee MDPI, Basel, Switzerland. This article is an open access article distributed under the terms and conditions of the Creative Commons Attribution (CC BY) license (http:/ / creativecommons.org/licenses/by/4.0/). 